\title{
Disciplinarity and the Rhetoric of Science:
}

\section{A Social Epistemological Reception Study}

William J. White

Penn State Altoona

Altoona, $P A$

Poroi 10.2 (December 2014)

Keywords: Alan G. Gross, bibliometrics, citation analysis, reception studies, rhetoric of science, social epistemology

The rhetoric of Newton's first paper-riveting to this day-was that of youth: brash and brilliant, relying for its persuasive effect on a clash of principles, a decisive confrontation, clearly and unequivocally presented. In contrast...the rhetoric of the Opticks was that of late middle age: a canny and successful attempt to transform a youthful invention into a durable inheritance.

-Alan G. Gross, Starring the Text (2006, 72)

In 2006, ten years after the appearance of a second edition of his book The Rhetoric of Science, Alan Gross published an extensive revision (a "major refiguring," in his own words) of his original attempt to frame a disciplinary identity for the rhetoric of science (Gross, 1990a: $1^{\text {st }}$ edition, 1996: $2^{\text {nd }}$ edition). While the second edition in and of itself marks a slight retreat from the radical position of the first-with its provocative hypothesis that science is rhetorical "without remainder" (Gross, 1990a, 33)-the third edition seems to stand as the emblem of a much more thoroughgoing volte-face, with its contents extensively revised, replaced, and reordered. Even its title changed, to Starring the Text: The Place of Rhetoric in Science Studies. The difference between the far more confident and expansive original title and the revamped one recapitulates in brief the shift in Gross's thinking-or, perhaps more properly, in his strategy-over the space of more than a decade and a half. As rhetoricians of science, concerned as we are with the way that texts are deployed to garner intellectual and institutional support for scholarly efforts, we must find Gross's move to be of extraordinary interest, and not only for self-regarding 
reasons. As a case study in disciplinarity and its discontents, Gross's shift from announcing the existence of a field in 1990 to making the case for its place at the multi-disciplinary table of science studies in 2006 promises to be instructive.

Before proceeding, some discussion of the nature of disciplinarity is warranted. Within science, a discipline acts both through and upon its adherents (see Prior, 1994), organizing knowledge-producing resources in response to institutional pressures and intellectual exigencies (Good, 2000) while at the same time establishing the object of inquiry for its members ontologically (Shepherd, 1993). Sullivan (1996) notes a further tension, in that scientists are expected to respect the traditions of their field but at the same time required to make novel contributions to it (224). He describes disciplinarity as operating via orthodoxieshierarchical systems of canonical narratives, doctrines, methods, and commonplaces that represent the shared vision of a field (226-229). In their work, scholars legitimate themselves in the context of a discipline by "projecting an orthodox, yet progressive, ethos" (233), signaling knowledge and acceptance of most of a field's paradigmatic touchstones while challenging a few in order to say something relevant and worthwhile. In this way, disciplines are able to engage in knowledge production despite a deeply conservative impulse that, in seeking to sustain an existing community and maintain its intellectual rigor, serves as a barrier to the new (Wilder, 2005).

From this perspective, the function of a discipline is primarily evaluative, serving to order the activities of scholars within a disciplinary community. To the extent that Gross's move from The Rhetoric of Science to Starring the Text marks a retreat from explicit disciplinary claims, the recalcitrance of disciplinarity is made more clearly visible to us. In other words, since disciplines are not natural and inevitable orderings of the world, but are instead the contingent outcomes of human action, it takes effort to create, sustain, and defend them-and sometimes that effort will meet resistance.

\section{Acts of Reference as Signs of Discipline}

This investigation is a reception study in the rhetoric of science (Paul, Charney, and Kendall, 2001), reflexively applied to the rhetoric of science itself. This is familiar ground, to be sure (Ceccarelli, 2005), but this study augments previous efforts at disciplinary self-reflection in the rhetoric of science by examining 
scholarly citations to Alan Gross's The Rhetoric of Science and Starring the Text in context in order to describe the uses to which other scholars put it. If "the production of science is born of its reception," as Harris asserts, then such an approach can provide insight into the way disciplines are constituted in scholarly discourse (Harris, 2005, 254).

Citations provide access to the discursive constitution of disciplines in science, as long as one is prepared to stipulate their rhetorical character-specifically, as multivalent forensic metonyms: i.e., as figures of speech oriented toward truth-claims and capable of multiple interpretations by virtue of their referentiality (see Amsterdamska and Leydesdorff, 1989; Cano, 1989; Cozzens, 1989; Gilbert, 1977; Small, 1978; Wouters, 1999). It should be noted that pointed caveats about the limitations of citations as measures of scientific work have been issued (Edge, 1979; Ferber, 1986; Zuckerman, 1987). More recently, Baldi asserts that there is little support for a "constructionist" perspective on citations in which they persuade by drawing upon the cognitive authority of high-status authors rather than merely acknowledging intellectual influence per the norms of citation behavior (Baldi, 1998). Note, however, that this charge proceeds from a rather blinkered view of how citations might operate rhetorically in scholarly writing. Writers need not rely be relying on another author's "high status" and may yet still be seeking to persuade by making a reference to that author's work. An alternate line of criticism notes how citation analysis serves to reify its object of study (i.e., a scholarly community) in a way that renders it amenable to the operations of institutional power (Hicks and Potter, 1991). Nonetheless, once we posit citations as rhetorical, it follows that their employment establishes disciplinary ties among authors as well as discursive ties among texts. Paul suggests that examining citation patterns in conjunction with the specifics of a text in which those citations appear permits "insights into the community in which a text is created" (Paul, 2000, 186). As Gilbert says:

It is important to note that an author, in choosing one collection of papers to cite, is not only providing support for his [sic] own paper, but is also implicitly displaying an allegiance to a particular section of the scientific community; namely, that section which is collectively of the opinion that the cited papers deserve (affirmative or negational) citation. Moreover, in citing certain papers, the author...is...contributing...to the overall consensus of his [sic] research area (Gilbert, 1977, 117). 
This discipline-defining quality of citations allows them to be thought of as micro-level efforts at what Fuller calls

interdisciplinary interpenetration (Fuller, 1993, 64). In citing another's work, in other words, an author is attempting discursively to position that work in a conceptual space that is fundamentally disciplinary in character, in the sense that citations produce (a) aggregations of individual work that constitute the discipline's knowledge base (i.e., a research front and the history of intellectual contributions that led there), and (b) aggregations of individual authors that constitute the discipline as a professional collective (Leydesdorff, 1998). We will return to Fuller's concept of interpenetration, using it as a tool for examining how scholars cite Gross in text.

\section{Drafted into the Science Wars}

Before looking at specific citation contexts (i.e., how Gross is cited in text within scholarly articles), it will be useful to examine the broader situation in which those citations occur. This account begins by discussing author co-citations with Gross within the literature that refers to The Rhetoric of Science. Author co-citation analysis (White, 1990; White and Griffith, 1982) is a bibliometric method (i.e., a quantitative technique that uses the characteristics of a text-based corpus as data) that analyzes the patterns of cooccurrence of scholars on reference lists to map the intellectual structures of academic communities; it assumes that author names represent their oeuvres. The first part of the analysis here is straightforward and limited, serving only as a point of entry to a broader discussion. It identifies an "ego-centered" co-citation network (Wasserman and Faust, 1994, 42) with Gross as "ego" and those authors most frequently appearing in the same reference lists with him as "alters." The point of this procedure is to characterize the intellectual climate (a) within which specific citations to Gross's work should be read, and (b) that shaped the exigence driving Gross's subsequent alterations to The Rhetoric of Science.

Between 1990 and 2011 there were 248 citations to any of the three editions of Gross's book (i.e., Gross, 1990a, 1996, 2006) recorded in the Web of Knowledge database (ISI, 2012). To obtain a subset to examine, complete citation data were obtained for all articles citing Gross from 1990 through 2004-i.e., before the publication of Starring the Text, on the premise that these references constituted the reception of Gross's work to which the third edition was a response. This resulted in a matrix of 156 citing articles (i.e., $63 \%$ of all citations to any edition of Gross's book) by 4927 cited authors. Table 1 shows the authors most co-cited with 
Gross within those articles (i.e., appearing in the same reference list with him) in the data set.

Table 1

Gross and Authors Most Co-Cited With Him, 1990-2004

\begin{tabular}{|l|l|l|l|}
\hline Author & Mean & Std Dev & Sum \\
\hline GROSS_AG & 0.955 & 0.210 & 149 \\
\hline LATOUR_B & 0.429 & 0.495 & 67 \\
\hline BAZERMAN_C & 0.288 & 0.453 & 45 \\
\hline MYERS_G & 0.276 & 0.447 & 43 \\
\hline KUHN_TS & 0.231 & 0.421 & 36 \\
\hline PRELLI_LJ & 0.212 & 0.408 & 33 \\
\hline SHAPIN_S & 0.192 & 0.394 & 30 \\
\hline KNORRCETINA_KD & 0.186 & 0.389 & 29 \\
\hline FOUCAULT_M & 0.179 & 0.384 & 28 \\
\hline FULLER_S & 0.154 & 0.361 & 24 \\
\hline WOOLGAR_S & 0.128 & 0.334 & 20 \\
\hline PERELMAN_C & 0.122 & 0.327 & 19 \\
\hline HARAWAY_DJ & 0.122 & 0.327 & 19 \\
\hline GILBERT_GN & 0.122 & 0.327 & 19 \\
\hline COLLINS_HM & 0.115 & 0.319 & 18 \\
\hline HACKING_I & 0.109 & 0.312 & 17 \\
\hline SIMONS_HW & 0.109 & 0.312 & 17 \\
\hline HARDING_SG & 0.103 & 0.303 & 16 \\
\hline RORTY_R & 0.103 & 0.303 & 16 \\
\hline DEAR_P & 0.103 & 0.303 & 16 \\
\hline MULKAY_M & 0.096 & 0.295 & 15 \\
\hline POPPER_KR & 0.096 & 0.295 & 15 \\
\hline TOULMIN_SE & 0.096 & 0.295 & 15 \\
\hline FEYERABEND_PK & 0.096 & 0.295 & 15 \\
\hline BLOOR_D & 0.096 & 0.295 & 15 \\
\hline PERA_M & 0.096 & 0.295 & 15 \\
\hline
\end{tabular}

Note. "Mean" refers to the \% of cases in which the co-cited author appears. Gross appears in fewer than $100 \%$ of cases because self-citations were removed.

Theoretically, the set of those most co-cited with a focal author, as Gross is here, serves to position that author within a conceptual space, with author names serving metonymically to represent their work. In the case of Gross, those who appear on reference lists with him frequently are associated with (a) rhetoric and text-focused studies of science as writing, including the rhetoric of science (i.e., 
Bazerman, Dear, Myers, Pera, Perelman, Prelli, Simons), ${ }^{1}$ (b) philosophy of science (Feyerabend, Hacking, Kuhn, Popper) and of knowledge (Foucault, Fuller, Rorty), and particularly (c) sociology of science, particularly that concerned with the social construction or epistemological relativism of scientific knowledge (Bloor, Collins, Haraway, Harding, Knorr-Cetina, Latour, Mulkay, Shapin, Woolgar). Those citing Gross may do so for a variety of reasons, but in aggregate the patterns of co-citation suggest that his work is generally seen as occupying an intellectual position relevant to the intersection of those concerns.

This perception of Gross should not be surprising, given the nature of the claims made in his book. "If scientific texts are to be analyzed rhetorically," he declares, Aristotelian strictures regarding the scope of rhetoric need to be discarded and "the spirit of the first Sophistic must roam free" (Gross, 1990, 3). As Trevor Melia reminds us, that spirit is a kind of epistemic skepticism that informs a world-view in which persuasion is, however reluctantly, conceded to mediate between knowledge and truth, since the latter is not available with any certainty to human mind (Melia, 1992). And while it is possible to read such an invocation in a modest way-as a call for playful experimentation, perhaps-critics both from within rhetoric or speech communication as a field (e.g., Campbell and Benson, 1996; Gouran, 1992) and from outside. (Agassi, 1999; Wynn, 1992) consistently take Gross to be suggesting a radical transformation of our conceptions of both rhetoric and science.

${ }^{1}$ It would require an essay of some length to adequately encompass the intellectual and disciplinary distinctions among this group of scholars. Perelman is associated with a neo-Aristotelian reclamation, revitalization, and extension of the rhetorical tradition. His New Rhetoric (with Olbrechts-Tyteca, 1969) is a seminal work. Gross places Bazerman (an "English professor" [1990b, 305]) and Prelli, along with himself, among the "first generation" of scholars enacting an "emerging rhetorical consciousness" in the study of science (Gross, 2008). Simons is an early figure in the rhetoric of inquiry more generally (see Simons, 1980, 1990, 1999). Myers' perspective is literary critical. Dear is an historian of science. Both have written on rhetoric and science (Melia, 1992). Pera comes in for criticism from Gross for theoretical incoherence: "I do not see how Pera can profess a deflationary metaphysics, a metaphysics that embodies a notion of reference wholly internal to discourse, and at the same time, affirm a deflationary view of rhetoric" (Gross 1995b, 254). Campbell and Benson discuss several of these authors, assigning Gross and Myers to the radical rhetoric of science; Bazerman, Prelli, and Pera (whom they identify as a philosopher of science) to the moderate program; and Dear as exemplifying the "literary moderate" in the rhetorical turn in science studies (Campbell and Benson, 1996). 
In The Rhetoric of Science, Gross sought to show that rhetoric was fundamentally constitutive of science by pointing to the vital role of rhetoric in the enactment of scientific rationality. Specifically, he offered demonstrations of (1) the heuristic value of analogy (Gross, 1996, 21-32), (2) the persuasive character of seemingly objective taxonomy (33-53), and (3) the dynamic presence of narrative in scientific argument (54-65). He argued for a concept of realism - an "essentially contested" term (193-194)that is congenial to a rhetorical perspective on science. This motivational realism asserts that "the existence of mindindependent entities" is a belief particularly well suited to the conduct of science (200). However, according to Gross, truth emerges elsewhere-not from the correspondence of theory with reality, but from the correspondence of theory with experience, both of which are "in our heads" (Gross, 1996, 202).

It should be acknowledged that this methodological phenomenalism or agnosticism with respect to reality is characteristic of other so-called "radical" programs in science studies. For example, Bloor's "strong program" in the sociology of knowledge made the assumption of "symmetry," i.e., that both correct and incorrect beliefs were to be explained as outcomes of the same process, because it would be incoherent for sociological explanations of why people hold certain beliefs to rely on the correspondence of those beliefs with reality as a causal factor in some cases and not in others (Bloor, 1976). Latour's "anthropology" of laboratory science goes even further, arguing for a tangled hybridity of human actors, non-human objects, and immaterial ideas such that "the fate of facts...is in later users' hands" (Latour, 1987, 259; Latour and Woolgar, 1979). He concludes that knowledge is therefore reflexive, helping to constitute the world that it purports to describe (Latour, 1988; Woolgar, 1988).

To be fair, Ceccarelli notes that "when asked to bracket the philosophical issue and talk about the practice of rhetorical criticism with respect to the realism/anti-realism debate, Alan Gross acknowledges that a scholar must at the very least hold to Arthur Fine's conception of 'common sense reality' (which one assumes to exist but which cannot be characterized independently of the observer)" (Ceccarelli, 2001, 326, n. 2). Nonetheless, the authors most closely associated with Gross via co-citation ties, particularly the philosophers and the sociologists, have come in for heavy criticism about their relativistic disregard for science's ability to get at truth (see, e.g., Cole, 1997; Haack, 1997; Kenshur, 1997; McGuire and Melia, 1989). So Gross's work is implicated in the "Science Wars" that fulminated in the 1990s. Gross himself found 
this fact regrettable. "Surely," he said, "there is something wrong with using another human being's work as a missile in a war not of his making" (Gross, 2000, 449).

In any event, his critics certainly interpret Gross as taking sides with respect to the broader issues in the study of science. Melia notes that in addition to drawing on a small but growing rhetoric of science literature, Gross "depends on congenial studies deriving from the 'Strong Program' in the sociology of knowledge from which he is nevertheless anxious to differentiate his own undertaking" (Melia, 1992; Bloor, Collins, et al., 101). Gouran finds it "unfortunate" that in attempting to describe the "vital role" that rhetoric plays in science, "Gross becomes so concerned with deprivileging science he ironically seeks to privilege rhetoric in ways that are not warranted by its current epistemological status" (Gouran, 1992, 273).

Agassi is less gentle, saying that Gross confuses "rhetoric as garnish with rhetoric as the main dish" (Agassi, 1999, 33). He claims to be unconvinced by Gross's arguments. "That style matters is trivially true and that style is all that matters is trivially false" (329). He goes on to say that "the translation of [Gross's] book to remove its exaggerations...will remove from it the absurd thesis and land it in the trivial one" (329). Ultimately, he finds Gross underinformed ("Pierre Duhem and Henri Poincaré disputed the matter; we should not expect Gross to be familiar with all this," 334), and warns rhetoricians and others of their ilk to stay on the margins of real science Agassi and Wynne are leery of Gross's disciplinary aspirations for the rhetoric of science (Agassi, 1999; Wynne, 1992). Agassi relies on sarcasm. Gross has declared rhetoric of science to be, "a real academic discipline," Agassi observes. "Since all study is legitimate, and any area may be deemed a field or a discipline, the message is that rhetoric deserves a university department. This means much bread; hence, faultfinders may expect a mean rebuttal" (Agassi, 1999, 329). Wynne by contrast is earnest. She fears that "an acceptance of the rhetoric of science would be sociological death," since Gross's analytic assumption that the meaning of a text is relatively easy to obtain amounts to a psychologically reductionist privileging of the intentionality of the author that would "obviate the intellectual enterprise of sociology altogether” (Wynne, 1992, 93).

\section{The Very Idea of Rhetoric}

By the time of Agassi's attack (a late hit, to be sure), Gross had already begun to retreat from the strong position laid out in the first edition of the book -the claim that science is rhetorical 
"without remainder" (Gross, 1990a, 33), and grounded in a belief in the thoroughgoing social construction of reality. By 1994, Gross would explain that the book was not, as accused, intended to show "'that scientists are really just rhetoricians, which is nonsense', but that scientists are engaged in the process of persuasion in all of their professional and intellectual activities, not only in the forum, but also in the laboratory, the field, and the study" (Gross, 1994, 3).

In 1996, the second edition of The Rhetoric of Science was augmented with a prefatory apologia that attempted to summarize developments since its original publication (This preface would form the bulk of the first chapter of Starring the Text). It positioned the first edition as the product of a particular historical moment, which it had been necessary to declare the existence of a field called rhetoric of science in order for the perception to exist that there was in fact such a field at all (Gross, 1996, viii). The book's contents then demonstrated that nascent discipline's possibility, breadth, and potential for insight. Writing six years after the first edition, Gross called for the next generation of rhetoricians of science to build on this foundation and create a coherent field. He envisioned a well-coordinated and philosophically well-grounded intellectual endeavor-a discipline indeed-that would bring together disparate threads of research in order to move beyond the conceptual boundaries and methodological limitations of the field.

The relationship between philosophy and rhetoric had been a persistent concern of Gross's (see, e.g., Gross, 1990b, 1995a), but the debate among rhetoricians over Gaonkar's challenge to the globalization of rhetoric, exemplified as he saw it by the rhetoric of science, seemed to crystallize this concern, driving many of the accommodations Gross would subsequently make. Gaonkar found it striking that rhetoric should be taken by so many as a "hermeneutic metadiscourse" capable of redescribing other discourses and thus dissolving them into itself superordinately (Gaonkar, 1993, 258). In its origins it was limited in scope to the courts, the assembly, and the funeral or festival ground, and in application to the production of speech rather than its interpretation. Previous efforts to expand the reach of rhetoric, Gaonkar argues, had failed. The classical rhetorical vocabulary had proven itself "far too narrow, far too normative, and far too rationalistic" to sustain a neo-Aristotelian program of criticism in the mid-2oth century, in the wake of which failure followed a pluralization of critical methods (which nonetheless concealed a recuperation of the classical tradition) and an ongoing tendency toward the globalization of rhetoric, facilitated by the work of Kenneth Burke who had remarked that, "Wherever there is 
persuasion, there is rhetoric. And wherever there is 'meaning', there is 'persuasion"' (Gaonkar, 1993, 262; see Burke, 1950, 172, cited in Schiappa, 2001, 261). According to Gaonkar's analysis, any coherent scheme for producing a "rhetoric of X" (291-292) requires (a) a more satisfying theory of the subject than the humanistic valorization of rhetor-as-agent that characterized the classical tradition, (b) the ability to accommodate a wider range of discursive categories than classical rhetoric possessed, and (c) a theoretical vocabulary that permits falsification and thereby corrigibility (Gaonkar, 1993, 263-264). Gaonkar identified the rhetoric of science as a site where the historical forces operating on universalized rhetoric-a disciplinary dialectic of repression and recognition-were clearly in evidence and were thus amenable to examination (Gaonkar, 1993, 265).

Gross was among those singled out for criticism by Gaonkar, who found him unable to convincingly link his professed (if not actually all that much in evidence, said Gaonkar) neo-Aristotelian methodology with his social constructionist, SSK-aligned theoretical allegiances (Gaonkar, 1993, 282-285). Tellingly, Gaonkar noted Gross's concern with "starring the text," a term taken from Barthes, meaning to foreground or otherwise privilege the artifacts of discourse (Gaonkar, 1993, 283).

Initially, Gross seems not to have been terribly alarmed by Gaonkar's accusations. ${ }^{2}$ He regarded them "less as dismissal than as admonition" to avoid the rote rhetorical re-description of texts, to strive for theoretical reflexivity, to forthrightly address intertextuality, and to employ case studies more systematically (Gross, 1993, 304).

Certainly, as the impresario of the conference session at which Gaonkar's paper was first presented and co-editor of the collection of essays in which it was ultimately published (Keith and Gross, 1997) following its initial print appearance (Gaonkar, 1993), Gross must have expected the colloquy to be salubrious. Even at his most radical, Gross was committed to philosophically coherent rhetoric of science. "There is nothing wrong with rhetoricians doing philosophy," he claimed, "so long as they get it right....To validate the philosophy we undoubtedly need, we must make it our business to cross the line, to talk to philosophers on their own turf" (Gross, 1990b, 305).

2 Although other readers have found Gross's "fretfully titled" response replete with anxiety (Harris, 2009, 352). 
In any case, Gross clearly took Gaonkar's concerns to heart. When the second edition of The Rhetoric of Science appeared, readers noted a new tentativeness on his part, even as he continued to argue for the disciplinary prospects of the rhetoric of science (Lyne, 1999). "Gaonkar's essay represents a reflective moment in which to meditate on the methodological limitations of the first generation of rhetoric of science," Gross says, "limitations that a second generation [among whom he numbers a more seasoned version of himself] will address" (Gross, 2006, 14). And while the debate surrounding Gaonkar's critique was "fruitless ... vituperative ... [and] best forgotten" (Gross and Gurak, 2005, 242), Gross insists that the essay marks an inflection point for rhetoricians of science of all sorts (Gross, 2008, for example)-despite the fact that he seems to be the only one affected in this way (Harris, 2009; Keränen, 2006).

Gross's subsequent work has decidedly been informed by Gaonkar's admonitions. For example, Gross and his colleagues attempt a more systematic appraisal of 17th century scientific writing, gathering "a large, representative sampling of texts from three journals" (Gross, Harmon, and Reidy, 2000, 373) and interpreting the results in such a way as to reveal their sociological implications. Already in this work Gross is beginning to take the position that will motivate his refiguring of The Rhetoric of Science: "As rhetoric becomes even further integrated as a method within the sociology of scientific knowledge...scientific communities will more often be seen as communities whose communicative and persuasive practices constitute necessary conditions to the creation of new knowledge" (Gross, 1996, 371).

\section{A Bigger Picture}

Gross, to be sure, is reacting to the critical response to his work. Examining how Gross's work is referred to in text when cited more generally-when other scholars try to use it, in other wordsprovides a complementary perspective to the critical reception of The Rhetoric of Science. To select a coherent subset of the 156 articles citing Gross for the purpose of citation context analysis, an analysis of their bibliographic coupling was performed (Diodato, 1994, 12-13; Martyn, 1964). This procedure involves the computerized calculation of which articles in a corpus tend to cite the same or similar authors. 3

3A pair of articles is said to be "bibliographically coupled" when one or more of the same authors appears on both reference lists. The more authors that appear, the stronger is the coupling between the pair of 
The citation matrix of 156 citing articles by 4927 cited authors was transformed using network analysis software (Borgatti, Everett, and Freeman, 2002) into a 156-by-156 citing article bibliographic coupling matrix, where the intersection of rows and columns indicates the number of cited authors any given pair of articles held in common. The bibliographic coupling matrix was then examined using hierarchical clustering, a procedure that creates a series of groupings of the citing articles at increasingly higher thresholds for authors in common clustering (Wasserman and Faust, 1994, 381383). At the lowest level-with one author (i.e., Gross) in commonall the articles belong to the same cluster. At the highest level, each article stands in isolation, assuming that no pair of articles share the exact same list of author references. (We in fact know from Table 1 that the next most frequently occurring author after Gross, Bruno Latour, appears in only about $43 \%$ of the articles).

As an intermediate level of coupling permits broad patterns to be identified within the corpus, it was decided to choose the lowest clustering "partition" that put at least half of the articles into a group rather than leaving them as isolates. The partition that met this criterion grouped together articles that held a minimum of 5 authors in common. This left only $48.7 \%$ of the articles as isolates; the next higher partition would have left $55.1 \%$ as isolates. In order to enable the visualization of the dataset, the isolates were removed and the remaining clusters were subjected to blockmodeling and multi-dimensional scaling procedures, which (a) treat the clusters established by prior analysis as nodes connected by bibliographic coupling ties and (b) graphically represent those ties by mapping them and the nodes they connect out in a two- dimensional space (Wasserman and Faust, 1994, 287-289; 394-397). Figure 1 displays the results of those procedures. Each cluster is labeled with a descriptive name based on article titles within the cluster and sized according to the number of articles in it. Lines connect those clusters that have co-citation ties at a level greater than the mean of the block matrix as a whole; isolated clusters are indicated but their locations in the figure are not meaningful.

Figure 1 below serves as a data reduction device; by enabling the structure of the entire corpus of articles to be visualized it allows subsets of putatively similar articles to be identified for closer examination. Where the clusters are small, the thematic or other

articles. Analysis of bibliographic clustering thus does not reveal how cited authors are clustered (that is called co-citation analysis); instead, it identifies groups of citing articles with similar citation patterns whose content then must be examined to determine what thematic or other similarities the citing articles possess. 
connection among the articles is usually easy to discern. In three cases, for example, pairs of articles with the same first author and similar topical foci are identified (i.e., O'Donoghue: Philosophy of Psychology, Safran: Medical Informatics, and Mercer: Citation Classification). As the clusters grow larger, thematic connections become less focused, and the labels assigned to them become mere convenience, a shorthand description rather than an analytic black box. For example, the six articles in the cluster labeled

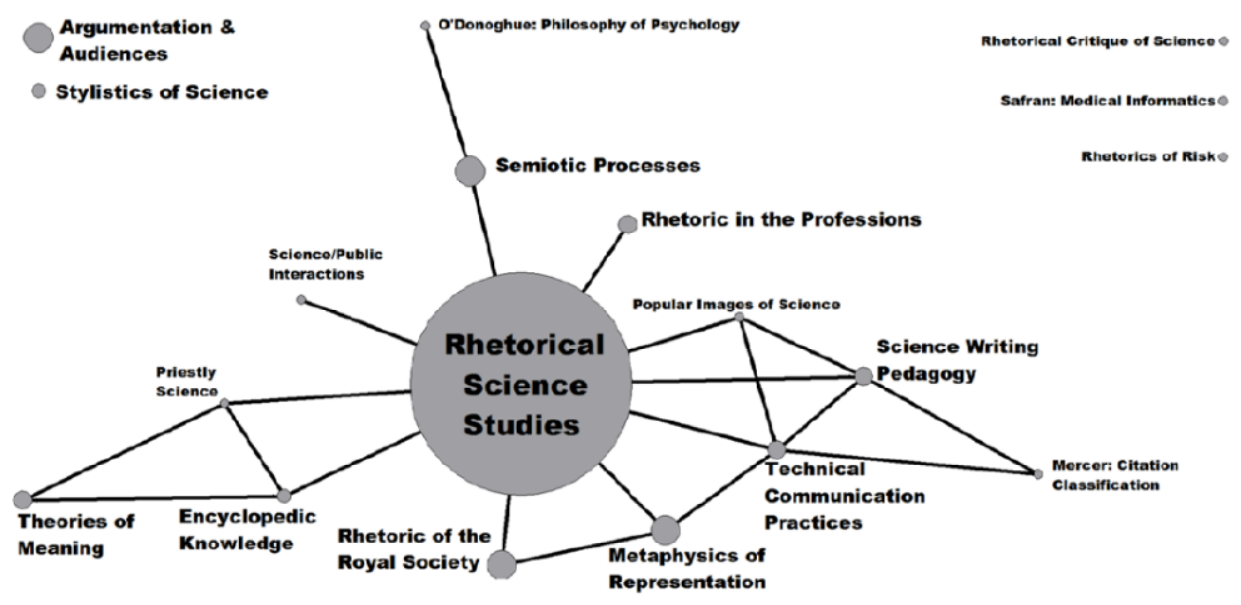

Figure 1. Bibliometric coupling clusters for articles citing Gross, 1990 or Gross, 1996

Biological Images include discussions of visual representation in the biological sciences and medicine (Crawford, 1996; Douard, 1995; Keirns, 1999) as well as arguments about scientific interpretation and authority using examples and illustrations drawn mainly from biology (Abir-Am, 1995; Allchin, 2003; Haack, 1998). The theme emerges after some exploration of the cluster's contents, and it is possible that a different reader would find other connections among the pieces grouped together by bibliographic coupling and thus give it a slightly different identifier.

Thus, the label for the large central grouping in Figure 1-called Rhetorical Science Studies, since to call it the Rhetoric of Science would be at this point begging the question- reflects the sense that these 45 articles are in the main concerned with the scholarly analysis of science and its history in a way that foregrounds rhetoric and the rhetorical and addresses issues of epistemology and knowledge production more generally. Figure 2 allows the various conceptual foci of this cluster to be visualized by presenting a "word cloud" (from wordle.net) of its title words. In this image, words are scaled according to the frequency with which they recur among the article titles. "Science" is far and away the most common, followed by "rhetoric" in second place, with a third tier containing the words 
"rhetorical," "politics," "public," "history," and "knowledge." Quaternary terms contributing to the theme of the cluster include "metaphor," "understanding," "discourse," "narratives," and "invention" as well as "Darwin."

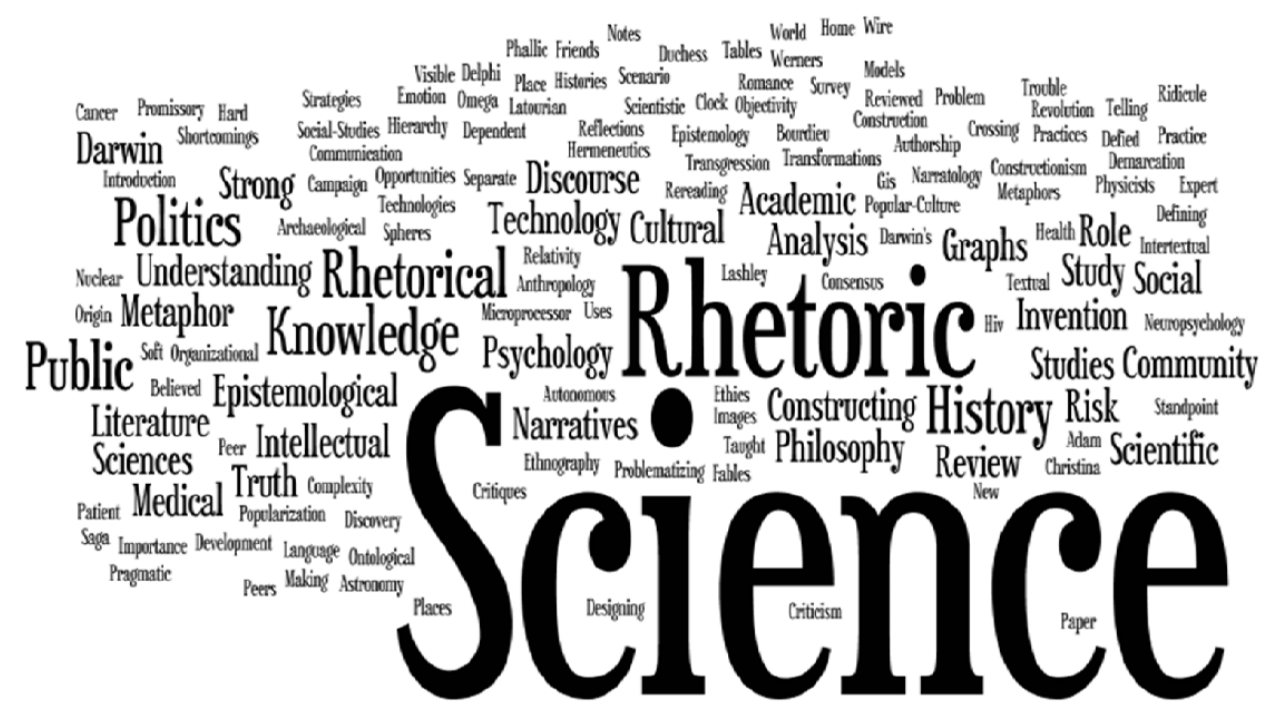

Figure 2. "Word Cloud" for Rhetorical Science Studies cluster

The Rhetorical Science Studies cluster of Figure 1 will be the focus of the remainder of this paper. However, before moving forward it should be noted that Figure 1 presents an interesting view of the field in which Gross is implicated as a scholar. Centered upon rhetorical science studies, it ramifies in one direction toward an unself-conscious rhetoric of science focused on scientists' use of linguistic resources to produce disciplined knowledge and in another direction toward the pragmatic scholarship of scientific, technical, and professional writing with an emphasis on the historical development of forms of written science. Tenuous connections to the scientometric (i.e., Mercer: Citation Classification) and the psychological (i.e., O'Donoghue: Philosophy of Psychology) literatures can also be glimpsed.

\section{Citation as Interpenetration:}

\section{A Social Epistemological Method}

It is time now to return to the concept of interdisciplinary interpenetration and to disciplinarity more generally. Fuller advocates a social epistemology that is intensely interested in the question of disciplinarity (Fuller, 1988). He sees discipline as the fulcrum upon which internal and external (or sublime and profane) strategies of justification for scientific activities are balanced. He suggests that disciplines, via their commitment to establishing and maintaining disciplinary boundaries, are the fundamental vehicles 
for the legitimation of knowledge enterprises. By 1993, Fuller has made explicit his rhetorical conception of disciplinarity, regarding disciplinary boundaries as emerging contingently and continuing conventionally rather than inevitably and necessarily.

Fuller discusses the operation of disciplinarity in the context of the interactions of entire fields-"classical" with "naturalistic" epistemology (Fuller, 1993, 69-101), the history and philosophy of science (HPS) with science and technology studies (STS) (186-224), the sociology of scientific knowledge (SSK) with artificial intelligence (AI) research (139-185), and even the social sciences with the physical (102-138)-in terms intended to evoke the accommodations and sticking-points navigated in the encounters of disciplinary communities (Fuller 1993). As Fuller sees it, interdisciplinary interpenetration takes one of four forms (60-65, and elsewhere): (1) incorporation, in which one discipline positions itself as successor to another; (2) excavation, in which one discipline positions itself as diverging from another; (3) sublimation, in which one discipline positions another as ancillary to itself; and (4) reflexion, in which a discipline interrogates its own constitution.

It does not take a very large conceptual leap to imagine applying Fuller's broad-brush conception of disciplinary dynamics in a pointillist fashion, seeing individual acts of citation as operating to position an individual work in ties of incorporation, excavation, sublimation, and reflexion with other works. This requires some reformulation of Fuller's concepts, of course, such that incorporation be taken to mean instances where prior work is presented as instrumental to a current one; excavation, where prior work is presented as somehow in error or needing correction; sublimation, as related but tangential; and reflexion, as essential to the current one but problematic in some way4. In other words, this investigation takes citation as a basic move in discipline-building at the intellectual level, involving one work building in

4While this scheme is similar to previous implementations of categories for citation context coding (Cano, 1989; Chubin and Moitra, 1975; Moravcsik \& Murugesan, 1975), particularly in classifying uses of citations as affirmative or negational and in regarding some uses as perfunctory, it has the advantage of occupying the four corners of a semiotic square (Greimas, 1983), and thus of delineating a more-or-less complete set of conceptual categories. In this case, "incorporation" serves as a simple positive term (S), opposed by "excavation" as a simple negative (not-S). The complex negative term (anti-S) is then "sublimation" (neither S nor not-S) while the complex positive term (anti not-S) is "reflexion" (both S and not-S). 
(incorporation), digging out (excavation), papering over (sublimation), or holding up (reflexion) another. Essentially, this amounts to an argument by operationalization, an assertion that the dynamics of interpenetration said to be operating at the level of entire disciplines by Fuller also describe individual acts of scholarship, a kind of fractal model of the sciences in which it is "fish scales" (D. T. Campbell, 1969) all the way down.

\section{The Citation Fortunes of Alan Gross}

Forty of the 45 articles in the Rhetorical Science Studies cluster were obtained and the places in each article at which Gross was cited were found. Those places were interpreted as falling into one of the four categories of interdisciplinary interpenetration discussed above. Of the 40 articles examined in this group, 13 (32.5\%) appeared to be incorporation, 5 (12.5\%) excavation, 19 (47.5\%) sublimation, and 3 (7.5\%) reflexion. Each category is briefly presented in turn.

\section{INCORPORATION}

A citation was classified as incorporation if Gross was identified as an authoritative source for a certain claim, idea, or thought useful to the citer's work. This category could be said to include Chubin and Moitra's "affirmative essential" classifications, both basic and subsidiary (Chubin and Moitra, 1975). Of the 13, four appear in psychology journals while the others appear in science studies (3), rhetoric and speech communication (3), education (1), sociology (1), and women's studies (1). Incorporative references were typically succinct, and took forms like these:

[1] I draw heavily on the work of Alan Gross, who showed how Rheticus's logic of discovery was a narrative of conversion (Brown, 1994, 4).

[2] Gross has referred to the 'self-effacement' of the scientist to characterize the way in which the utilitarian language of the empirical disciplines systematically emphasizes the data or theory over the researcher as an individual (Madigan, Johnson, and Linton, 1995, 433).

\section{EXCAVATION}

A citation was classified as excavation if Gross was identified as the source of a problematic claim, thought, or idea that the citer explicitly rejected. Such citations would be negational in Chubin and Moitra's (1975) scheme. Interestingly, most of these appeared 
in interdisciplinary fora: two were published in philosophy journals and one appeared in a sociolinguistics journal. One each appeared in a science studies journal and a rhetoric/composition journal. Two examples follow:

[3] The main reason for this [erroneous adherence to "ontological relativity" (151), despite its drawbacks], I suggest, is the widely shared view among contemporary thinkers in various disciplines-philosophy of science included-that language (or "discourse") constitutes the absolute horizon of intelligibility for everything we can possibly claim to know about ourselves and the physical world [note]. See for instance [cites Gross and four others]. For realist counter-arguments from a range of philosophical perspectives, see also [cites 10 others]" (Norris, 1997, 154, 170)

[4] The issue [of the role of argumentative reasoning or 'witcraft' in the public understanding of science"] arises in a particularly pertinent way in Gross's brief remarks on the creation/evolution controversy, which he characterized as a debate between "biology and theology"....However, this misses the crucial point that very act of describing the controversy as between biology and theology is already a nonindependent description (Locke, 2002, 102-103).

\section{SUBLIMATION}

A citation was classified as sublimation if Gross was presented as an exemplar of an intellectual enterprise tangential or parallel albeit still relevant to the citer's work. In Chubin and Moitra's terms, these references could be classified as "affirmative supplementary" (Chubin and Moitra, 1975). Most efforts at sublimation occurred outside the field of rhetoric/composition, with one cite in a speech communication journal falling into this category. Eight appeared in science studies journals (construed broadly to include history and philosophy of science). Four appeared in interdisciplinary social science journals. Two appeared in anthropology journals and one each appeared in a management journal, a political commentary journal, an education journal, and a chemistry Festschrift. Typically, the reference to Gross appears among a list of other ostensibly related citations. Two examples follow. 
[5] The ritual of presenting experiments and the rhetoric of reporting unnatural events and unusual observations have been scrutinized" [footnote citing H.W. Simons, Gross, and Pera \& Shea] (Harley, 1999, 408).

[6] Shinn and Whitley, editing a volume on "expository science," point to the essential similarities among all discourse that involves science, a topic that has been taken up in studies of the rhetoric of science. [endnote] For work on the rhetoric of science, see [Bazerman, Myers, and Gross] (Lewenstein, 1995, 404, 431-432)

\section{REFLEXION}

A citation was classified as reflexion if Gross was the object of a detailed assessment or evaluation whose main function seemed to be to salvage his work from what the citer considered to be a problematic or insufficiently well articulated theoretical commitment. They appeared in journals of rhetoric and speech communication. Two examples follow.

[7] Alan Gross exploits this concept [of allegiance] without actually linking it to the word "allegiance" in his discussion of Copernicus and Rheticus. He uses the word in passing without comment...but he makes much of the relationship a bit later....When Gross uses verbs like "turn one's back on" or "desert" in reference to abandoning the Ptolemaic system, he tacitly acknowledges the concept of allegiance (Sullivan, 1994, 253).

[8] According to Gross, science is thoroughly rhetorical, since the production of scientific knowledge is a matter of persuasion and consensus. By implication, the rational reconstruction of science...has to be replaced by a "rhetorical reconstruction of science"...Gross's conception is the most radical in contemporary rhetorical studies of science (Ginev, 1999, 249). 
Table 2

Citation Context Categories by Journal Type, Comparing Observed Frequencies With Those Expected By Chance

\begin{tabular}{|l|l|l|l|l|}
\hline $\begin{array}{l}\text { Citation } \\
\text { Context }\end{array}$ & $\begin{array}{l}\text { Journal Type } \\
\text { Rhet/Comp \& } \\
\text { Speech Comm }\end{array}$ & $\begin{array}{l}\text { Sciences } \\
\text { Studies }\end{array}$ & Other & Total \\
\hline Incorporation & $3(+0.4)$ & $2(-1.6)$ & $8(+1.2)$ & 13 \\
\hline Excavation & $1(+0)$ & $1(-0.4)$ & $3(+0.4)$ & 5 \\
\hline Sublimation & $1(-2.8)$ & $8(+2.8)$ & $10(+0)$ & 19 \\
\hline Reflexion & $3(+2.4)$ & O(-0.8) & o(-1.6) & 3 \\
\hline Total & 8 & 11 & 21 & 40 \\
\hline
\end{tabular}

Note. Observed frequencies differ from expected, $.2(6)=16.6, p<.05$. Because some expected frequencies are less than 5 , the chance of Type I error may be greater than normal.

Table 2 summarizes the distribution of citation context classifications across types of journals, classified as either (1) rhetoric/composition and speech communication, (2) science studies, or (3) other. Although the small number of cases means that statistical inferences are uncertain, the results are in line with what we would expect were the citation context categories indeed linked to interpenetrative disciplinary moves as argued above. Within rhetoric of science's "home" in its English- and communication-specific journals, space exists for reflexion, which ultimately regards a cited work as meriting a recuperative interrogation. The implication is that "science studies" (i.e, the social and cultural investigation of science, using various social scientific methodologies and perspectives) is not rhetoric of science's "home territory," since the technique of sublimation positions a cited scholarly field as outside boundaries of the citing scholar's work.

It is in the context of trying to make science studies, broadly construed, more welcoming to rhetorical approaches that Gross's move in recasting The Rhetoric of Science as Starring the Text should be understood. This essay briefly examines that move next.

\section{A Major Refiguring: Starring the Text}

Criticism from within and without the field of rhetoric seems to have motivated Gross to make changes in how he talked about the 
role of rhetoric in relation to science and science studies. Certainly the change of titles for the book exemplifies this shift, as do the changes in its organization between editions.

Table 3 describes the internal changes between the editions. The only change between the first and second edition is the inclusion of the preface summarized above, the effect of which was to "reposition" the disciplinary claims of the earlier work (Lyne, 1999, 639). The "third edition" (Starring the Text) raises the 1996 Preface to the dignity of the first chapter (albeit revised and augmented with new material that updates Gross's account of the history of rhetoric of science), re-numbering but otherwise leaving in place what had been the first three chapters so that they become Chapters 2, 3, and 4. Chapters 4, 5, and 6 in The Rhetoric of Science are scrapped while Chapters 7 through 10 are moved up to fill in the gap and reordered, becoming the new Chapters 5 through 8 . New material is added to create Chapters 9 and 10. Chapter 11 remains in place and a new Chapter 12 replaces the old one. The chapters retained between the second and third editions are all renamed. The point of all of these changes, both substantive and nominal, seems to have been to position the book as demonstrating the range and utility of rhetorical approaches to studies of science. This is in contrast to the original argument of the book, which was to demonstrate the fully fledged capability of rhetoric to account for the outcomes of science. 
Table 3

Content Comparison of Gross (1990/1996) and Gross (2006)

\begin{tabular}{|c|c|c|c|}
\hline \multicolumn{2}{|c|}{ Rhetoric of Science } & \multicolumn{2}{|c|}{ Starring the Text } \\
\hline Chapter & Chapter Title & Chapter & Chapter Title \\
\hline Preface & The Rhetoric of Science 1996 & 1 & $\begin{array}{l}\text { The Achievements of the Rhetoric of } \\
\text { Science }\end{array}$ \\
\hline 1 & Rhetorical Analysis & 2 & $\begin{array}{l}\text { The Justification of the Rhetoric of } \\
\text { Science }\end{array}$ \\
\hline 2 & Analogy in Science & 3 & The Kind of Rhetoric Science Is \\
\hline 3 & Taxonomic Language & 4 & $\begin{array}{l}\text { The Possibility of a Complete Rhetorical } \\
\text { Description of Science: Taxonomy as } \\
\text { Example }\end{array}$ \\
\hline 4 & The Tale of DNA & & \\
\hline 5 & Style in Biological Prose & & \\
\hline 6 & $\begin{array}{l}\text { The Arrangement of the } \\
\text { Scientific Paper }\end{array}$ & & \\
\hline 8 & Newton's Rhetorical Conversion & 5 & $\begin{array}{l}\text { The Possibility of a Complete Rhetorical } \\
\text { Description of Science: Newton's Opticks } \\
\text { as Example }\end{array}$ \\
\hline 10 & The Origin of the Origin & 6 & $\begin{array}{l}\text { The Generation of Scientific Knowledge: } \\
\text { The Evolution of Evolution in Darwin's } \\
\text { Notebooks }\end{array}$ \\
\hline 9 & $\begin{array}{l}\text { Peer Review and Scientific } \\
\text { Knowledge }\end{array}$ & 7 & $\begin{array}{l}\text { The Initial Certification of Knowledge: } \\
\text { Peer Review as the Institutionalization of } \\
\text { the Consensus }\end{array}$ \\
\hline \multirow[t]{3}{*}{7} & $\begin{array}{l}\text { Copernicus and Revolutionary } \\
\text { Model Building }\end{array}$ & 8 & $\begin{array}{l}\text { The Spread of Scientific Knowledge: The } \\
\text { Initial Acceptance of Heliocentricity }\end{array}$ \\
\hline & & 9 & $\begin{array}{l}\text { The Incorporation of Claims Into } \\
\text { Practice: Closure in Science and Its } \\
\text { Philosophy }\end{array}$ \\
\hline & & 10 & $\begin{array}{l}\text { Science and Society: Curing Occupational } \\
\text { Medicine }\end{array}$ \\
\hline 11 & The Emergence of Social Norm & 11 & $\begin{array}{l}\text { Compatible Insights Between Sociology } \\
\text { and Rhetoric: Priority as a Social Norm }\end{array}$ \\
\hline 12 & $\begin{array}{l}\text { The Social Drama of } \\
\text { Recombinant DNA }\end{array}$ & & \\
\hline \multirow[t]{2}{*}{ Epilogue } & Reference Without Reality & & \\
\hline & & 12 & $\begin{array}{l}\text { Complementary Insights Among } \\
\text { Disciplines: The Example of } \\
\text { Incommensurability }\end{array}$ \\
\hline
\end{tabular}

The appearance of Starring the Text so far has proven of interest foremost to rhetoricians and communication scholars, with reviews appearing in the Journal of Communication, the Journal of Business and Technical Communication, and IEEE Transactions on Professional Communication as well as Isis, a history of science journal (although, as with Lyne's earlier review, it is written by a rhetorician). The tone of these reviews is in general respectful, with Johnson (2008) the most admiring, lauding Gross's more modest 
ambitions and the vision he advances of rhetoric as facilitator of discussions, engenderer of consensus, provocateur of conflict, and creator of arenas for resolution. Janas (2008) compliments the increased coherence of Starring the Text, and several reviewers acknowledge Gross's topical range and abilities of synthesis. But both Keränen (2006) and Paul (2008) take issue with Gross's use of Gaonkar (1993) as a major inflection point and critical touchstone in the rhetoric of science (see also Harris, 2009). Several seem to regret Gross's efforts to exorcise the radical epistemological inferences that characterized The Rhetoric of Science. Janas says that Gross has moved from "revolutionary prophet to conventional practitioner," suggesting that one of the main features of the original book is a historical significance now lacking in the revision. Paul intends to stick with The Rhetoric of Science in her classes, since the value of the work for her is how it is a product of its historical moment. Wynne (2007) seems not to believe Gross's renunciation of radicalism, given that the exorcism of that language is incomplete in the nuts and bolts of the chapters that have been carried forward from the older editions, regardless of how the transitions have been rewritten. In short, reviewers of Starring the Text seem to acknowledge Gross's intentions, but to have doubts about the contemporaneous relevance of the revised book or its project. "Those seeking the growing socially salient, policy-focused vein of rhetoric of science will need to look elsewhere," Keränen says (Keränen, 2006, 867).

The same pattern seems to hold true for citations to the 2006 book. Of the 80 articles that cited at least one version of the book between 2006 and 2011, 19 (24\%) cited Starring the Text. This includes five book reviews. Removing those as well as five unavailable articles left 9 articles, four of which were classified as incorporation, one as excavation, three as sublimation, and one as reflexion. These are proportionally indistinguishable from the distribution across citation context categories of the Rhetorical Science Studies cluster, .2(3)=15.4, n.s., although Starring the Text shows slightly greater incorporation (44\% vs. $33 \%$ ) and slightly less sublimation (33\% vs. 48\%) than does The Rhetoric of Science.

Should those proportions hold steady over time, signaling a real difference in the use of the different versions of the book, it may indicate that Gross's movement away from asserting the disciplinarity of rhetoric of science will have made it easier for his work to be actively used by the broader science studies community-at the cost, however, of weakening the claim of the rhetorician of science to a unique disciplinary identity. As Isager and Just say in a similar context, "the rhetoricians gradually 
disappear from the picture, leaving only their basic tools behind" (Isager and Just, 2005, 252). Given that its indiscriminate "globalization" has been cited as a source of the philosophical incoherence of rhetoric of science (Collier, 2005; Gaonkar, 1993), this may not be a bad thing. However, from a social epistemological standpoint, it commits to what may be called a non-disciplinary strategy, wherein "legitimacy for the field is sought primarily through association with and service to 'real' disciplines" (Shepherd, 1993, 88). "We can argue for the importance of maintaining such a non-disciplinary field," he goes on, "but [we] will constantly struggle against charges of incoherence and triviality" (89).

\section{Conclusion}

This study began to explore the disciplinarity of the rhetoric of science by using Alan Gross's movement away from the radical rhetoric of science as its stalking horse. It describes the "refiguring" of The Rhetoric of Science into Starring the Text as Gross's response to internal and external criticism of the epistemological position implicit in the first edition. The criticism was largely the consequence of the strategy of disciplinarity the first text adopted, in which rhetoric is asserted to be ontologically foundational of science (cf. Shepherd, 1993). This position aligned Gross in the eyes of external readers with the radical (i.e., non-Mertonian, social constructionist, epistemologically relativist) wing of science studies. Additionally, it helped prompt internal criticism within the field of communication in general as well as rhetoric specifically about the unwarranted globalization or totalization of rhetoric.

In the decade and a half following the publication of The Rhetoric of Science, much of Gross's work amounted to a walkingback of his proclamation of a field called rhetoric of science, culminating in a revamped, retitled version of his book. Meanwhile, others have made use of The Rhetoric of Science in their own work, using it primarily as a device for identifying "rhetoric of science" as a field related to science studies (sublimation) and to some degree as a source of useful or important claims, methods, or other insights (incorporation) within psychology, science studies, and speech communication. Although the evidence is inconclusive, it may be that the changes Gross made to the book, particularly the title change, make it less useful in the former capacity as well as less relevant as what Lakatos called a programmatic exemplar for rhetoricians of science (Lakatos, 1970)-even if it does turn out to be more congenial to incorporation into science studies work. 
Additionally, the model of citation practices offered here provides a conceptual frame for making sense of the empirical citation context schema offered in the bibliometric literature. It thus serves as a contribution to a theory of citations capable of grappling with their multivalent character (Leydesdorff, 1998). It is at root a rhetorical theory, acknowledging the agency of scholars in their decisions about whom to cite, but it positions that agency within the confines of disciplinarity such that citers are powerfully motivated to cite others in a way that positions their work as simultaneously different from but relevant to the work of other scholars. It thus goes some way toward answering the question of how citations persuade, to the extent that they do.

Copyright (C) 2014 William J. White

\section{Reference List}

Abir-Am, P. G. "'New' trends in the History of Molecular Biology." Historical Studies in the Physical and Biological Sciences 26:1 (1995): 167-196.

Agassi, J. "The Rhetoric of Science" [book review]. Philosophy of the Social Sciences 29:2 (1999): 329-335.

Allchin, D. "Scientific Myth-conceptions." Science Education 87:3 (2003): 329-351.

Amsterdamska, O. and L. Leydesdorff. "Citations: Indicators of Significance.” Scientometrics 15:5-6 (1989): 449-471.

Baldi, S. "Normative Versus Social Constructivist Processes in the Allocation of Citations: A Network-Analytic Model." American Sociological Review 63(6) (1998): 829-846.

Bloor, D. Knowledge and Social Imagery. Chicago, IL: University of Chicago Press, 1979.

Borgatti, S. P., M. G. Everett, and L. C. Freeman. Ucinet for Windows: Software for Social Network Analysis. Harvard, MA: Analytic Technologies, 2002.

Brown, R. H. "Logics of Discovery as Narratives of Conversion: Rhetorics of Invention in Ethnography, Philosophy, and Astronomy." Philosophy and Rhetoric 27:1 (1994): 1-34.

Burke, K. A Rhetoric of Motives. New York: Prentice Hall, 1950.

Campbell, D. T. "The Ethnocentrism of Disciplines and the Fish-Scale Model of Omniscience.” In M. Sherif \& C. W. Sherif (Eds.) Interdisciplinary Relationships in the Social Sciences (pp. 328348). Chicago, IL: Aldine, 1969. 
Campbell, J. A., \& K. R. Benson. "The Rhetorical Turn in Science Studies.” Quarterly Journal of Speech 82:1 (1996): 74-109.

Cano, V. "Citation Behavior: Classification, Utility, and Location." Journal of the American Society for Information Science 40:4 (1989): 284-290.

Ceccarelli, L. "Rhetorical Criticism and the Rhetoric of Science." Western Journal of Communication 65:3 (2001): 314-329.

-"A Hard Look at Ourselves: A Reception Study of Rhetoric of Science." Technical Communication Quarterly 14:3 (2005): 257-265.

Chubin, D. E. and S. D. Moitra. "Content Analysis of References: Adjunct or Alternative to Citation Counting?" Social Studies of Science 5:4 (1975): 423-441.

Cole, S. "Voodoo Sociology: Recent Developments in the Sociology of Science.” In P. R. Gross, N. Levitt and M. W. Lewis (Eds.) The Flight From Science and Reason. (Pp. 274-287). New York: New York Academy of Sciences, 1997.

Collier, J. H. "Reclaiming Rhetoric of Science and Technology: Knowing in and About the World." Technical Communication Quarterly 14:3 (2005): 295-302.

Cozzens, S. E. "What Do Citations Count? The Rhetoric-First Model." Scientometrics 15:5-6 (1989): 437-447.

Crawford, T. H. "Imaging the Human Body: Quasi-Objects, QuasiTexts, and the Theater of Proof." PMLA: Publications of the Modern Language Association of America 111:1 (1996): 66-79.

Diodato, V. Dictionary of Bibliometrics. New York: Haworth Press, 1994.

Douard, J. W. and E. J. Marey. "Visual Rhetoric and the Graphic Decomposition of the Body [book review]." Studies in History and Philosophy of Science 26:2 (1995): 175-204.

Edge, D. O. "Quantitative Measures of Communication in Science: A Critical Review." History of Science 17 (1979): 102-134.

Ferber, M. A. "Citations: Are They an Objective Measure of Scholarly Merit?” Signs: Journal of Women in Culture and Society 11:2 (1986): 381-389.

Fuller, S. Social Epistemology. Bloomington, IN: University of Indiana Press, 1988.

Fuller, S. Philosophy, Rhetoric, and the End of Knowledge: The Coming of Science \& Technology Studies. Madison, WI: University of Wisconsin Press, 1993. 
Gaonkar, D. P. "The Idea of Rhetoric in the Rhetoric of Science." Southern Communication Journal 58 (1993): 258-295.

Gilbert, G. N. "Referencing as Persuasion.” Social Studies of Science 7 (1977): 113-122.

Ginev, D. "From a Strong Hermeneutics of Science to a Strong Rhetoric of Science." Philosophy and Rhetoric 32:3 (1999): 247281.

Good, J. M. M. "Disciplining Social Psychology: A Case Study of Boundary Relations in the History of the Human Sciences." Journal of the History of the Behavioral Sciences 36:4 (2000): 383-403.

Gouran, D. S. "The Rhetoric of Science by Alan G. Gross [book review]." Quarterly Journal of Speech 78:2 (1992): 272-273.

Greimas, A. J. Structural Semantics: An Attempt at a Method. Lincoln, NE: University of Nebraska Press, 1983.

Gross, A.G. The Rhetoric of Science. Cambridge, MA: Harvard University Press, 1990a.

-------"Rhetoric of Science is Epistemic Rhetoric.” Quarterly Journal of Speech, 76:3 (1990b): 304-306.

-“What if We're Not Producing Knowledge? Critical Reflections on the Rhetorical Criticism of Science." Southern Communication Journal 58 (1993): 301-305.

------“"The Role of Rhetoric in the Public Understanding of Science.” Public Understanding of Science 3:1 (1994): 3-23.

“Alan Gross on The Discourses of Science by Marcello Pera." Rhetoric Society Quarterly 25 (1995): 252-254.

-------The Rhetoric of Science (2nd ed.). Cambridge, MA: Harvard University Press, 1996.

------ "The Science Wars and the Ethics of Book Reviewing." Philosophy of the Social Sciences 30:3 (2000): 445-450.

------- Starring the Text: The Place of Rhetoric in Science Studies. Carbondale IL: Southern Illinois University Press, 2006. “Rhetoric of Science.” International Encyclopedia of Communication, 2008.

Gross, A. and L. J. Gura. "Guest Editors' Introduction.” Technical Communication Quarterly 14:3 (2005): 241-247.

Gross, A. G., Harmon, J. E., and M. S. Reidy. "Argument and 17thCentury Science: A Rhetorical Analysis with Sociological Implications." Social Studies of Science 30:3 (2000): 371-396. 
Haack, S. “Towards a Sober Sociology of Science.” In P. R. Gross, N. Levitt and M. W. Lewis (Eds.) The Flight From Science and Reason. (Pp. 259-265). New York: New York Academy of Sciences, 1997.

Haack, S. "Misinterpretation and the 'Rhetoric of Science': Or, What Was the Color of the Horse? (On the Question of Interpretation in the Natural Sciences)." Proceedings of the American Catholic Philosophical Association 72 (1998): 69-91.

Harley, D. "Rhetoric and the Social Construction of Sickness and Healing." Social History of Medicine 12:3 (1999): 407-435.

Harris, R. A. "Reception Studies in the Rhetoric of Science." Technical Communication Quarterly 14:3 (2005): 249-255.

"Alan Gross and the Rhetoric of Science." Perspectives on Science, 17:3 (2009): 346-380.

Hicks, D and J. Potter. "Sociology of Scientific Knowledge: A Reflexive Citation Analysis, or Science Disciplines and Disciplining Science.” Social Studies of Science 21 (1991): 459-501.

Isager, C., and S. N. Just. "Rhetoricians Identified: A Call to Interdisciplinary Action and How it Resonated in the Field of Rhetoric." Philosophy and Rhetoric 38:3 (2005): 248-258.

ISI. Web of Knowledge. Thomson Reuters, 2012.

Janas, M. "Starring the Text: The Place of Rhetoric in Science Studies." IEEE Transactions on Professional Communication 51:2 (2008): 235-236.

Johnson, J. "Starring the Text: The Place of Rhetoric in Science Studies [book review]." Quarterly Journal of Speech 94:1 (2008): 126-130.

Keirns, C. "Seeing Patterns: Models, Visual Evidence and Pictorial Communication in the Work of Barbara McClintock." Journal of the History of Biology 32:1 (1999): 163-196.

Keith, W. and A. G. Gross, (Eds.) Rhetorical Hermeneutics: Invention and Interpretation in the Age of Science. Albany, NY: SUNY Press, 1997.

Kenshur, O. "The Allure of the Hybrid: Bruno Latour and the Search For a New Grand Theory.” In P. R. Gross, N. Levitt \& M. W. Lewis (Eds.) The Flight From Science and Reason (Pp. 288297). New York: New York Academy of Sciences, 1997.

Keränen, L. "Starring the Text: The Place of Rhetoric in Science Studies [book review].” Journal of Communication 56:4 (2006): 866-867. 
Lakatos, I. "Falsification and the Methodology of Scientific Research Programmes." In I. Lakatos \& A. Musgrave (Eds.) Criticism and the Growth of Knowledge (Pp. 91-196). Chicago, IL: University of Chicago Press, 1997.

Latour, B. Science in Action: How to Follow Scientists and Engineers Through Society. Cambridge, MA: Harvard University Press, 1987.

_-“The Politics of Explanation: An Alternative.” In S. Woolgar (Ed.) Knowledge and Reflexivity: New Frontiers in the Sociology of Knowledge (Pp. 155-176). Newbury Park, CA: Sage, 1988.

Latour, B. and S. Woolgar. Laboratory Life: The Social Construction of Scientific Facts. Beverly Hills, CA: Sage, 1979.

Lewenstein, B. V. "From Fax to Facts: Communication in the Cold Fusion Saga." Social Studies of Science 25:3 (1995): 403-436.

Leydesdorff, L. “Theories of Citation?" Scientometrics 43:1 (1998): 525.

Locke, S. "The Public Understanding of Science: A Rhetorical Invention." Science Technology \& Human Values 27:1 (2002): 87-111.

Lyne, J. "The Rhetoric of Science by Alan G. Gross [book review]." Isis 90:3 (1999): 638-639.

Madigan, R., S. Johnson, and P. Linton. "The Language of Psychology: APA style as Epistemology.” American Psychologist 50:6 (1995): 428-436.

Martyn, J. "Bibliographic Coupling." Journal of Documentation 20:4 (1964): 236.

McGuire, J. E and T. Melia. "Some Cautionary Strictures on the Writing of the Rhetoric of Science." Rhetorica 7:1 (1989): 87-99.

Melia, T. "Essay Review." Isis 83:1 (1992): 100-106.

Moravcsik, M. J. and P. Murugesan. "Some Results on Function and Quality of Citations.” Social Studies of Science 5:1 (1975): 86-92.

Norris, C. "Ontological Relativity and Meaning-Variance: A CriticalConstructive Review." Inquiry: An Interdisciplinary Journal of Philosophy 40:2 (1997): 139-173.

Paul, D. "In Citing Chaos: A Study of the Rhetorical Use of Citations." Journal of Business and Technical Communication 14:2 (2000): 185-222. 
------“Starring the Text: The Place of Rhetoric in Science Studies." Journal of Business and Technical Communication 22:1 (2008): 116-120.

Paul, D., Charney, D. and A. Kendall. "Moving Beyond the Moment: Reception Studies in the Rhetoric of Science." Journal of Business and Technical Communication 15:3 (2001): 372-399.

Perelman, C. and L. Olbrechts-Tyteca. The New Rhetoric: A Treatise on Argumentation (J. Wilkinson \& P. Weaver, Trans.) Notre Dame, IN: University of Notre Dame Press, 1969.

Prior, P. "Response, Revision, Disciplinarity: A Microhistory of a Dissertation Prospectus in Sociology." Written Communication 11:4 (1994): 483-533.

Schiappa, E. "Second Thoughts on the Critiques of Big Rhetoric." Philosophy and Rhetoric 34:3 (2001): 260-274.

Shepherd, G. J. "Building a Discipline of Communication.” Journal of Communication 43:3 (1993): 83-91.

Simons, H. W. "Are Scientists Rhetors in Disguise? An Analysis of Discursive Processes Within Scientific Communities.” In E. E. White (Ed.) Rhetoric in Transition: Studies in the Nature and Uses of Rhetoric (Pp. 115-130). University Park, PA: Pennsylvania State University Press, 1980.

Simons, H. W. "Rhetorical Hermeneutics and the Project of Globalization.” Quarterly Journal of Speech 85:1 (1999): 86109.

Simons, H. W. (Ed.). The Rhetorical Turn: Invention and Persuasion in the Conduct of Inquiry. Chicago, IL: University of Chicago Press, 1990.

Small, H. G. "Cited Documents as Concept Symbols." Social Studies of Science 8 (1978): 327-340

Sullivan, D. L. "Galileo's Apparent Orthodoxy in his 'Letter to the Grand Duchess Christina'.” Rhetorica 12:3 (1994): 237-264.

--------“Displaying Disciplinarity.” Written Communication 13:2 (1996): 221-250.

Wasserman, S. and K. Faust. Social Network Analysis: Methods and Applications. Cambridge, England: Cambridge University Press, 1994.

White, H. D. "Author Co-citation Analysis: Overview and Defense." In C. L. Borgman (Ed.) Scholarly Communication and Bibliometrics (Pp. 84-106). Newbury Park, CA: Sage, 1990. 
White, H. D., \& Griffith, B. D. "Authors as Markers of Intellectual Space: Co-citation in Studies of Science, Technology, and Society.” Journal of Documentation 38:4 (1982): 255-272.

Wilder, L. "'The Rhetoric of Literary Criticism' Revisited: Mistaken Critics, Complex Contexts, and Social Justice." Written Communication 22:1 (2005): 76-119.

Woolgar, S. "Reflexivity is the Ethnographer of the Text." In S. Woolgar (Ed.) Knowledge and Reflexivity: New Frontiers in the Sociology of Knowledge (Pp. 14-36). Newbury Park, CA: Sage, 1988.

Wouters, P. "Beyond the Holy Grail: From Citation Theory to Indicator Theories." Scientometrics 44:3 (1999): 561-580.

Wynn, J. "Starring the Text: The Place of Rhetoric in Science Studies" Isis, 98:2 (2007): 433-434.

Wynne, A. "Playing with Fire: The Rhetoric of Science by Alan G. Gross [book review]." History of the Human Sciences 5:1 (1992): 87-94.

Zuckerman, H. "Citation Analysis and the Complex Problem of Intellectual Influence.” Scientometrics 12:5-6 (1987): 329-338. 